\title{
Evaluation of Integrated Management of Wild Radish (Raphanus raphanistrum) in Faba Bean in Waliso District of South West Shoa, Ethiopia
}

\author{
Shashitu Bedada Nigussie Hundesa Desalengn Gela Gectachew Bekele \\ EIAR, Ambo Agricultural Research Center. P. O. Box 37. Ambo, Ethiopia
}

\begin{abstract}
A field experiment was conducted from 2017 to 2018 to evaluate effective and economical integrated management package for the control of Raphanus raphanistrum in faba bean in Waliso District of South West Shoa, Ethiopia. The experimental design used was spilt plot design with two levels of plowing frequency assigned as main plot and eight weed management practice as sub plot in three replications. Data recorded on crop and weed related parameters. Results obtained indicated that the interaction effect of plowing frequency and combination of herbicides with hand weeding frequency significantly affected plant height, number of pods per plant, seeds per pod, crop biomass and grain yield of faba bean. The highest mean grain yield $(1541 \mathrm{~kg} / \mathrm{ha})$ was obtained from the interaction effect of plowing three times with application of pendimethalin at $3 \mathrm{lt} \mathrm{ha}^{-1}$ supplemented with once hand weeding at 30-35 days after sowing. This is followed by plowing three times and application of SMetolachlor at 1 litter ha-1 supplemented with twice hand weeding at 30-35 and 50-55 days after sowing that gave a mean grain yields of $1463 \mathrm{~kg} / \mathrm{ha}$. The interaction effect of plowing frequency and combination of herbicides with hand weeding frequency also significantly affected the weed population, weed plant height and biomass. The lowest R. raphanistrum population, height and biomass was obtained from the interaction of three times plowing and application of S-metolachlor at 1 litter ha ${ }^{-1}$ supplemented with twice hand weeding at 30-35 and 50-55 days after sowing. Economic analysis showed that trice plowing combined with application of Pendimethalin at 3 lt ha${ }^{1}$ supplemented by once hand weeding at 30-35 days after sowing gave the highest Net benefit (23174 birr) followed by three times plowing combined with application S-Metolachlor at $1 \mathrm{lt} \mathrm{ha}^{-1}$ supplemented by twice hand weeding. Therefore, three times plowing and application of S-Metolachlor herbicide supplemented by twice hand weeding at 30-35 and 50-55 DAS or three times plowing and application of Pendimethalin herbicide at $3 \mathrm{lt}^{\text {lt }} \mathrm{h}^{-1}$ supplemented with one time hand weeding at 30-35 DAS is recommended for economic control of R. raphanistrum in faba bean production.
\end{abstract}

Keywords: Raphanus raphanistrum, s-metolachlor, pendimethalin

DOI: $10.7176 / \mathrm{JBAH} / 10-5-02$

Publication date:March $31^{\text {st }} 2020$

\section{Introduction}

Wild radish (Raphanus raphanistrum) is a major weed of winter crops in southern and eastern Australia, and is particularly troublesome in cereal and brassica crops. It is thought to be poisonous to livestock. Reproduction is only by seed, which spread shorter distances by wind, water, animals and human activities. Dispersal via contaminated agricultural produce is thought to be the most significant means of long range spread (Retter and Harden, 2005).

Several exotic weed species have long been introduced to Ethiopia. Among these, $R$. raphanistrum is now causing a serious impact on crop and rangelands in Ethiopia. So far, there was no concrete evidence on how $R$. raphanistrum introduced into Ethiopia. The weed is extremely expanding on highlands ecology of the country and devastating cereals, pulses, oil crops and rangelands. It became a serious weed of crop and rangelands in West Shewa, particularly in Welmera and Cheliya; South West Shewa (Waliso) and Horo Guduru district in east Wellega zone of Oromiya, region.

According to farmers around Chaliya district (Gedo), R. raphanistrum was introduced during the war between Ethiopia and Italy (1930-1935) through Italy armed forces. Farmers say that the weed was brought to Gedo through horse feed contaminated with $R$. raphastirum seed and that it was first observed in Fortino area. Its distribution and spread is more restricted to the normal upland /drained type of grazing area rather than water logged grazing area (Shugute, unpublished, 2015). It is locally known as "Gomana Faranji" (French cabbage) possibly indicating its introduction from abroad (Personal communication). The weed has substantial impact on the native biodiversity of rangelands and arable lands by canopy covering, being toxic to animals and causes severe human health problems by making allergic reactions on hands while making hand weeding in field crops. Therefore, it has become an increasing serious problem in major crops as well as faba bean in the study area.

Results of field experiment conducted during 1997 -1998 at Shambu testing site indicated that Raphanus alone incurred $28.9 \%$ grain yield loss in bread wheat relative to the weeded check and effective control of this weed was obtained using mecoprop, 2,4-D and the tank mixture of both herbicide, and ioxynil + bromoxynil 
+mecoprop treated plots (Dhaba et al., 2005).

Cultural, chemical and biological weed control activities can exert a strong selective influence on the weed population (Chancellor, 1985). Thus, knowledge of the weed community structure is an important component of weed management, and is essential in setting priorities for management and research. Chemicals nowadays are expensive and are not environmentally friendly. Thus, "best mix" approach is currently advocated as Integrated Pest Management (IPM) involves logical combination of different compatible tactics for the control of pests (Brader, 1979).

Wild radish is among the major weeds found in Wolliso district. However, there is limited information regarding its management and its effect on the productivity of major crops particularly faba bean. Therefore, this trial was initiated with the objective to enhance faba bean crop yield by reducing $R$. raphanistrum weed infestation level using appropriate weed management options and evaluate effective and economical management package.

\section{Materials and Methods}

Description of study area

The study was conducted in Waliso districts of South West Shoa Zone of Oromiya Regional State on the farmer's field during the main cropping season of 2017 and 2018. Testing site was selected after field observation on the availability of naturally infested heavy and wide population of $R$. raphanisrtrum weeds at major Faba bean growing area.

\section{Treatments and experimental design}

The experiment was laid out as a split-plot design with three replications. The factors includes two plowing frequency (two times plowing and three times plowing) assigned as a main plot and eight weed management practices (S-metolachlor at $1 \mathrm{lt} \mathrm{ha}^{-1}$ supplemented by one hand weeding at 30-35 days after sowing (DAS); Smetolachlor at $1 \mathrm{lt} \mathrm{ha}^{-1}$ supplemented by twice hand weeding at 30-35 and 50-55 DAS; Pendimethalin at 3 lt ha ${ }^{-1}$ supplemented by one hand weeding at 30-35 DAS; Pendimethalin at $3 \mathrm{lt} \mathrm{ha}^{-1}$ supplemented by twice hand weeding at 30-35 and 50-55 DAS; twice hand weeding at 30-35 and 50-55 DAS; S-Metolachlor at 1 lt ha ${ }^{-1}$; Pendimethalin at $3 \mathrm{lt} \mathrm{ha}^{-1}$ and; weedy check were assigned as sub plot. The size of each sub plot was $5 \mathrm{~m} \mathrm{x} 4 \mathrm{~m}\left(20 \mathrm{~m}^{2}\right)$ with a distance of $1 \mathrm{~m}$ between plots and $1.5 \mathrm{~m}$ between blocks were left to avoid spray drift from adjacent plots. Faba bean variety Walki was sown at $200 \mathrm{~kg} / \mathrm{ha}$ with a spacing of $40 \mathrm{~cm}$ between rows and $5 \mathrm{~cm}$ between plants and DAP were applied at $100 \mathrm{~kg} / \mathrm{ha}$ at sowing time.

\section{Experimental procedures}

Land was prepared with oxen plough to fine soil bed which supports easy contact of the seed with soil. All other agronomic practices required for the crop were applied according to recommendation given for the crop.

Method of application: The required quantity of the herbicide was calculated and measured into manual knapsack sprayer with a pre-determined water volume for each plot and each herbicide was applied separately one day after sowing under non windy condition.

\section{Data collection}

Data on yield and yield components of faba bean like number of pods per plant, number of seeds per pod, grain yield, biomass, plant height, and 1000 seed weight were recorded. Total number of pods in 10 randomly selected plants in each plot was counted at harvest and expressed as the number of pods plant ${ }^{-1}$. From these pods, the seeds were counted to determine the number of seeds pod $^{-1}$.Thoused seeds were counted from each plot, and their weight was recorded. Above ground dry biomass weight was measured at physiological maturity from each plot. This was converted in to $\mathrm{kg} \mathrm{ha}^{-1}$. Grain yield $(\mathrm{kg})$ was recorded from each net plot area.

In addition, data on R. raphanisrtrum weed height, density/count after herbicide application and biomass at harvest was collected. R. raphanisrtrum weeds present in the experimental fields of all plots were recorded after application by placing a quadrat of $0.25 \mathrm{~m} \mathrm{X} 0.25 \mathrm{~m}$ randomly at two spots. Its height was measured from 10 randomly selected weeds before crop harvesting. Biomass was also measured during crop harvest from all plots. Partial budget analysis procedure was employed for economic analysis of herbicide application and it was carried out for faba bean yield

\section{Data analysis}

The data collected were subjected to analysis of variance using SAS software. Means that showed a significant difference were separated by least significant difference at 0.05 probability level by SAS (SAS, 2004).

\section{Economic analysis}

The partial budget analysis a described by CIMMYT (1988) was conducted to determine the economic feasibility 
of the weed management practice. Economic analysis was made using the prevailing market prices for inputs at planting and for the outputs at the time of crop harvest. It was calculated by taking in to account the additional input and labor cost involved and gross benefits obtained from weed management practices. Average yield was adjusted downward by $10 \%$ to reflect the difference between the experimental yield and the yield farmers could obtained from the same weed management practices as described by (CIMMYT, 1988). For economic evaluation, partial budget, value to cost ratio (VCR) and marginal analysis were used based on the local market price of the faba bean yield and herbicide cost, the cost of tillage and weeding were also taken from the farmers own practice.

\section{Results and Discussion \\ Plant height}

The result of mean separation from the two years data indicted in Table 1 showed that plant height was significantly influenced by the interaction effect of plowing frequency, application of herbicides and hand weeding. The highest mean plant height $(112.91 \mathrm{~cm})$ was obtained from the interaction effect of three times plowing + application of Pendimethalin at $3 \mathrm{lt} \mathrm{ha}^{-1}$ followed by three times plowing + application of S-metolachlor at $1 \mathrm{lt} \mathrm{ha}^{-1}$. However, the lowest mean plant height $(58.94 \mathrm{~cm}$ and $62.23 \mathrm{~cm})$ were obtained from twice plowing + application of $\mathrm{S}$ metolachlor at $1 \mathrm{lt} \mathrm{ha}^{-1}$ supplemented with twice hand weeding at 30-35 and 50-55 DAS and twice plowing + application of Pendimethalin at $3 \mathrm{lt} \mathrm{ha}^{-1}$ supplemented with twice hand weeding at 30-35 and 50-55 DAS, respectively. This indicates that three times plowing is more effective in increasing plant height as compared to twice plowing, but plant height was not influenced by application of herbicide and hand weeding (Table 1).

\section{Number of pods per plant}

Analysis of variance revealed that there is a high significant difference among the treatments in number of pods per plant (Table 1). Combined effect of two years data indicates that the highest mean number of pods per plant (7.5 and 7.4) was recorded from three times plowing + twice hand weeding at 30-35 and 50-55 DAS and three times plowing + application of S-metolachlor at 1 litter ha ${ }^{-1}$ supplemented with twice hand weeding at 30-35 and 50-55 DAS, respectively. This might be due to reduced weed competition for nutrient, moisture and light as result the crop get higher net assimilation rate thus retaining more flower. The development of more and vigorous leaves under low weed infestation might have also helped to improve the photosynthetic efficiency of crop and supported large number of pods (Hodgson and Blackman, 2005). However, the lowest mean number of pods per plant (5.3 and 5.6) was recorded from twice plowing + S-metolachlor at $1 \mathrm{lt} \mathrm{ha}^{-1}$ and twice plowing + Pendimethain at $3 \mathrm{lt}$ $\mathrm{ha}^{-1}$, respectively (Table 1). This result indicted that, three times plowing + twice hand weeding at 30-35 and 5055 DAS are the most effective followed by three times plowing + S-metolachlor $1 \mathrm{lt} \mathrm{ha}^{-1}+$ twice hand weeding at 30-35 and 50-55 DAS in increasing number of pods per plant in faba bean. These results are in line with Hadi et al. (2006) who observed an increased number of pods plant ${ }^{-1}$ where weed population was reduced by management techniques. Similarly, Pereira et al. (2015) and El-Metwally et al. (2008) sated that the number of pods produced per plant or maintained to final harvest depends on a number of environmental and management practices.

\section{Number of seeds per pod}

The interaction effect of different weed control options showed significant effect on number of seeds per pods of faba bean (Table 1). The highest mean number of seeds per pod (3.03) was obtained from the interaction effect of three times plowing + application of Pendimethalin $3 \mathrm{lt} \mathrm{ha}^{-1}$ supplemented with twice hand weeding at 30-35 and 50-55 DAS followed by three times plowing + application of Pendimethalin at $3 \mathrm{lt} \mathrm{ha}^{-1}$ supplemented with once hand weeding at 30-35 DAS which having (2.9) number of seeds per pod. These is might be due the reduced interference of weeds; the vigorous leaves might have helped to improve the photosynthetic efficiency of crop that support large number of seeds pod ${ }^{-1}$ which can have positive contribution for increment of grain yield. However, the lowest mean number of seeds per pod(2.45) was recorded from twice plowing + twice hand weeding at 30-35 and 50-55 DAS, but non-significant different existed in twice plowing + S-metolachlor at $1 \mathrm{lt} \mathrm{ha}^{-1}$, twice plowing + weedy check, three times plowing + S-metolachlor at $1 \mathrm{lt} \mathrm{ha}^{-1}+$ once hand weeding at 30-35 DAS, three times plowing + twice hand weeding at 30-35 and 50-55 DAS, three times plowing + S-metolachlor at 1 lt ha ${ }^{-1}$, three times plowing + Pendimethalin $3 \mathrm{lt} \mathrm{ha}^{-1}$ and three times plowing + weedy check (Table 1$)$. 
Table1. Effect of integrated $R$. raphanistrum weed management on plant height, number of pods per plant, number of seed per pod and biomass of faba bean at Waliso district during 2017/2018.

\begin{tabular}{|c|c|c|c|}
\hline Treatments & $\begin{array}{l}\text { Plant } \\
\text { height }\end{array}$ & $\begin{array}{l}\text { No of pods per } \\
\text { plant }\end{array}$ & $\begin{array}{l}\text { No seeds } \\
\text { /pod }\end{array}$ \\
\hline Year 2017 & $118.265^{\mathrm{a}}$ & $7.6625^{\mathrm{a}}$ & $2.5375^{b}$ \\
\hline Year 2018 & $52.740^{\mathrm{b}}$ & $4.9854^{b}$ & $2.8833^{\mathrm{a}}$ \\
\hline $\operatorname{LSD}(0.05)$ & 7.7315 & 0.5129 & 0.1184 \\
\hline $\begin{array}{l}\text { Twice plowing }+ \text { S-metolachlor } 1 \text { lt ha }{ }^{-1}+\text { once hand weeding at } \\
30-35 \text { DAS }\end{array}$ & 76.12 efg & 6.3 abcd & $2.867^{\mathrm{abc}}$ \\
\hline $\begin{array}{l}\text { Twice plowing }+ \text { S-metolachlor } 1 \mathrm{lt} \mathrm{ha}^{-}+\text {twice weeding at } 30- \\
35 \text { and } 50-55 \text { DAS }\end{array}$ & $58.94^{\mathrm{g}}$ & $5.92^{\mathrm{cd}}$ & $2.55^{\text {cde }}$ \\
\hline $\begin{array}{l}\text { Twice plowing }+ \text { Pendimethalin } 3 \mathrm{lt} \mathrm{ha}^{-1}+\text { once hand weeding at } \\
\text { 30-35 DAS }\end{array}$ & 73.18 efg & $6.52 \mathrm{abcd}$ & $2.8^{\text {abcd }}$ \\
\hline $\begin{array}{l}\text { Twice plowing }+ \text { Pendimethalin } 3 \mathrm{lt} \mathrm{ha}^{-1}+\text { twice weeding at } 30- \\
35 \text { and 50-55 DAS }\end{array}$ & $62.23^{\mathrm{g}}$ & $5.98^{\mathrm{bcd}}$ & $2.87^{\mathrm{abc}}$ \\
\hline Twice plowing + twice hand weeding at $30-35$ and $50-55$ DAS & 77.94 defg & 6.07 abcd & $2.45^{\mathrm{e}}$ \\
\hline Twice plowing + S-metolachlor $1 \mathrm{lt} \mathrm{ha}^{-1}$ & $76.49^{\text {efg }}$ & $5.33^{\mathrm{d}}$ & $2.533^{\text {cde }}$ \\
\hline Twice plowing+ Pendimethalin 3 lt ha $^{-1}$ & 93.44 abcde & $5.6^{\mathrm{d}}$ & $2.87^{a b c}$ \\
\hline Twice plowing + weedy check & $65.16^{\mathrm{fg}}$ & $5.8^{\mathrm{cd}}$ & $2.6^{\text {bcde }}$ \\
\hline $\begin{array}{l}\text { Three times plowing+ S-metolachlor } 1 \mathrm{lt} \mathrm{ha}^{-1}+\text { once hand } \\
\text { weeding at } 30-35 \text { DAS }\end{array}$ & $80.73^{\text {defg }}$ & $5.87^{\mathrm{cd}}$ & 2.533 cde \\
\hline $\begin{array}{l}\text { Three times plowing }+ \text { S-metolachlor } 1 \text { tha }^{-1}+\text { twice hand } \\
\text { weeding at } 30-35 \text { and } 50-55 \text { DAS }\end{array}$ & $86.00^{\text {cdef }}$ & $7.4^{\mathrm{ab}}$ & $2.8^{\text {abcd }}$ \\
\hline $\begin{array}{l}\text { Three times plowing }+ \text { Pendimethalin } 3 \text { it } \mathrm{ha}^{-1}+\text { once hand } \\
\text { weeding at } 30-35 \text { DAS }\end{array}$ & $104.14^{\mathrm{abc}}$ & $7.1^{\mathrm{abc}}$ & $2.90^{\mathrm{ab}}$ \\
\hline $\begin{array}{l}\text { Three times plowing+ Pendimethalin } 3 \mathrm{lt} \mathrm{ha}^{-1}+\text { twice hand } \\
\text { weeding at 3-35 and 50-55DAS }\end{array}$ & $89.38^{\text {bcde }}$ & $7.23^{\mathrm{abc}}$ & $3.03^{\mathrm{a}}$ \\
\hline $\begin{array}{l}\text { Three times plowing }+ \text { twice hand weeding at } 30-35 \text { and } 50-55 \\
\text { DAS }\end{array}$ & $99.18^{\mathrm{abcd}}$ & $7.5^{\mathrm{a}}$ & $2.73^{\text {abcde }}$ \\
\hline Three times plowing + S-metolachlor $1 \mathrm{lt} \mathrm{ha}^{-1}$ & $108.68^{\mathrm{ab}}$ & $6.25^{\mathrm{abcd}}$ & $2.47^{\mathrm{de}}$ \\
\hline Three times plowing + Pendimethalin 3 lt ha $^{-1}$ & $112.91^{\mathrm{a}}$ & $6.3^{\text {abcd }}$ & $2.78^{\mathrm{abcde}}$ \\
\hline Three times plowing + weedy check & $103.53^{\mathrm{abc}}$ & $6.02^{\mathrm{bcd}}$ & $2.58^{\text {bcde }}$ \\
\hline $\operatorname{LSD}(0.05)$ & 21.868 & 1.4508 & 0.3348 \\
\hline $\mathrm{CV}(\%)$ & 22.16 & 19.88 & 10.70 \\
\hline
\end{tabular}

Note: $C V=$ Coefficient of Variation, $L S D=$ Least significance difference, DAS=Days after sowing, $l t=$ litter,

Means followed by the same letter within a column are not significantly different at $0.05 p$

\section{Crop Biomass}

Result for crop biomass yield indicated that significant differences among treatments were observed (Table 2). The highest mean value of crop biomass $(4241.7 \mathrm{~kg} / \mathrm{ha})$ was obtained from the interaction effect of three times plowing + application of Pendimethalin $3 \mathrm{lt} \mathrm{ha}^{-1}$ supplemented with once hand weeding at 30-35 DAS, but as par with three times plowing + Pendimethalin at $3 \mathrm{lt} \mathrm{ha}^{-1}$ supplemented with twice hand weeding at 30-35 and 50-55 DAS, and three times plowing + S-metolachlor at $1 \mathrm{lt} \mathrm{ha}^{-1}+$ twice hand weeding at 30-35 DAS. However, the lowest mean value of crop biomass yield $(1883.3 \mathrm{~kg} / \mathrm{ha})$ was obtained from twice plowing + twice hand weeding at 30-35 and 50-55 DAS, but non significantly twice plowing+ S-metolachlor at $1 \mathrm{lt} \mathrm{ha}^{-1}$, twice plowing+ Smetolachlor at $1 \mathrm{lt} \mathrm{ha}^{-1}+$ twice hand weeding at 30-35 and 50-55 DAS, trice plowing + S-metolachlor at 1 litter ha1 . Therefore, three times plowing + application of pendamithaline at $3 \mathrm{lt} \mathrm{ha}^{-1}$ supplemented with once hand weeding at 30-35 DAS followed by three times plowing + application of pendimethalin at $3 \mathrm{lt} \mathrm{ha}^{-1}$ supplemented with twice hand weeding at 30-35 DAS are effective in increasing above ground biomass as compared to other treatments. The increased above ground biomass yield in these treatments might be due to utilization of resources more efficiently by the crop in the absence of the weed that resulted in higher final crop stand. Similar with present results, Alfonso et al. (2013) reported good suppression of weed growth by cultural and herbicidal control measures that lead to low competition by weeds for light, space and nutrients and in contrast the utilization of resources efficiently by the crop that lead to higher dry biomass production.

\section{Grain Yield}

Analysis of variance indicated that high significant difference among different treatments (Table2). The highest mean grain yield $(1541.2 \mathrm{~kg} / \mathrm{ha})$ was obtained as a result of interaction effect of three times plowing + application of pendimethalin at $3 \mathrm{lt} \mathrm{ha}^{-1}$ supplemented with once hand weeding at 30-35 DAS followed by three times plowing 
+ application of S-metolachlor at $1 \mathrm{lt} \mathrm{ha}^{-1}$ supplemented with twice hand weeding at 30-35 and 50-55 DAS having $1462.8 \mathrm{~kg} / \mathrm{ha}$ grain yield. But non significantly three times plowing + Pendimethalin at $3 \mathrm{lt} \mathrm{ha}^{-1}$ supplemented with twice hand weeding at 30-35 and 50-55 DAS, three times plowing + weedy check, twice plowing + S-metolachlor at $1 \mathrm{lt} \mathrm{ha-1}$ suplimented with once hand weeding at 30-35 DAS and three times plowing+ twice hand weeding at 30-35 and 50-55 DAS. However, the lowest mean grain yield $(748.3 \mathrm{~kg} / \mathrm{ha})$ was, however, recorded under interaction of twice plowing + application of S-metolachlor at $1 \mathrm{lt} \mathrm{ha}^{-1}$ followed by twice plowing + application of pendimethalin at $3 \mathrm{lt} \mathrm{ha}^{-1}$ (Table2). This result indicated that three times plowing + application of pendimethalin at $3 \mathrm{lt} \mathrm{ha}^{-1}$ supplemented by once hand weeding at 30-35 DAS and three times plowing + application of Smetolachlor at $1 \mathrm{lt} \mathrm{ha}^{-1}$ supplemented by twice hand weeding at 30-35 and 50-55 DAS were gave highest grain yield of faba bean as compared to other treatments. Similarly, research conducted at Holeta and Shamboo showed that repeated plowings before planting significantly increased grain yield of faba bean (Endale Asmare and Rezene Fessehaie, 1991; Tolera Abera and Daba Feyisa, 2004). Bellido et al. (2003) also reported pre-planting conventional tillage is productive than no tillage in three rainy years.

\section{Thousand seed weight}

High significant difference was observed among treatments on thousand seed weight (Table 2). Maximum mean thousand seeds weight $(696.75 \mathrm{~g})$ and $(693.47 \mathrm{~g})$ were obtained from the interaction of three times plowing + application of Pendimethalin at $3 \mathrm{lt} \mathrm{ha}^{-1}$ supplemented with twice hand weeding at 30-35 DAS and 50-55 DAS and twice plowing + weedy check, respectively, though most of means showed statistical parity. Whereas, the lowest value $(650.27 \mathrm{~g})$ was recorded from three times plowing + application S-metolachlor at 1 litter ha- ${ }^{-1}$ supplemented with twice hand weeding. This is because of the fact that as pods of faba bean per plant increases, seed size decreased to accommodate more pod clusters in a node.

Table 2. Effect of integrated $R$. raphanistrum weed management on grain yield and thousand seed weight of faba bean in Woliso district during 2017-2018

\begin{tabular}{|c|c|c|c|}
\hline Treatments & $\begin{array}{l}\text { Crop Biomass } \\
(\mathrm{Kg} / \mathrm{ha})\end{array}$ & $\begin{array}{l}\text { Grain } \\
\mathrm{kg} / \mathrm{ha}\end{array}$ & $\begin{array}{l}1000 \quad \text { seed } \\
\text { weight }(\mathrm{g})\end{array}$ \\
\hline Year 2017 & $3595.8^{\mathrm{a}}$ & $1333.27^{\mathrm{a}}$ & $665.919^{b}$ \\
\hline Year 2018 & $2320.8^{b}$ & $1025.35^{b}$ & $682.854^{\mathrm{a}}$ \\
\hline $\operatorname{LSD}(0.05)$ & 275.84 & 136.83 & 10.995 \\
\hline $\begin{array}{l}\text { Twice plowing }+ \text { S-metolachlor } 1 \mathrm{lt} \mathrm{ha}^{-1}+\text { once hand } \\
\text { weeding at } 30-35 \text { DAS }\end{array}$ & $2958.3^{\mathrm{cdef}}$ & $1379.3^{\mathrm{abc}}$ & $684.28 \mathrm{abc}$ \\
\hline $\begin{array}{l}\text { Twice plowing }+ \text { S-metolachlor } 1 \mathrm{lt} \mathrm{ha}^{-}+\text {twice weeding } \\
\text { at 30-35 and 50-55 DAS }\end{array}$ & $2425.0^{\text {efg }}$ & $982.2 \mathrm{def}$ & $662.03 \mathrm{bcd}$ \\
\hline $\begin{array}{l}\text { Twice plowing }+ \text { Pendimethalin } 3 \mathrm{lt} \mathrm{ha}^{-1}+\text { once hand } \\
\text { weeding at } 30-35 \text { DAS }\end{array}$ & $2791.7^{\mathrm{def}}$ & 1150.3 bcde & 666.25 abcd \\
\hline $\begin{array}{l}\text { Twice plowing+ Pendimethalin } 3 \mathrm{lt} \mathrm{ha}^{-1}+\text { twice weeding } \\
\text { at } 30-35 \text { and 50-55 DAS }\end{array}$ & $2775.0^{\mathrm{def}}$ & 1092.7 bcdef & $665.83^{\text {abcd }}$ \\
\hline $\begin{array}{l}\text { Twice plowing+ twice hand weeding at } 30-35 \text { and } 50-55 \\
\text { DAS }\end{array}$ & $1883.3^{\mathrm{g}}$ & $1108.3^{\text {bcdef }}$ & 678.50 abcd \\
\hline Twice plowing + S-metolachlor 1 lt ha ${ }^{-1}$ & $2241.7 \mathrm{fg}$ & $748.3^{f}$ & $656.32^{\mathrm{cd}}$ \\
\hline Twice plowing + Pendimethalin $3 \mathrm{lt} \mathrm{ha}^{-1}$ & $2725.0^{\text {def }}$ & $795.5^{\mathrm{ef}}$ & $657.52^{\mathrm{cd}}$ \\
\hline Twice plowing + weedy check & $2750.0^{\mathrm{def}}$ & $1147.2^{\text {bcde }}$ & $693.47^{\mathrm{a}}$ \\
\hline $\begin{array}{l}\text { Three times plowing }+ \text { S-metolachlor } 1 \mathrm{lt} \mathrm{ha}^{-1}+\text { once } \\
\text { hand weeding at } 30-35 \text { DAS }\end{array}$ & $3066.7^{\text {cde }}$ & $1271.8^{\mathrm{abcd}}$ & 673.62 abcd \\
\hline $\begin{array}{l}\text { Three times plowing+ S-metolachlor } 1 \text { tha }^{-1}+\text { twice } \\
\text { hand weeding at } 30-35 \text { and } 50-55 \text { DAS }\end{array}$ & $3625.0^{a b c}$ & $1462.8^{a b}$ & $650.27^{\mathrm{d}}$ \\
\hline $\begin{array}{l}\text { Three times plowing }+ \text { Pendimethalin } 3 \text { it } \mathrm{ha}^{-1}+\text { once } \\
\text { hand weeding at } 30-35 \text { DAS }\end{array}$ & $4241.7^{\mathrm{a}}$ & $1541.2^{\mathrm{a}}$ & $683.97^{a b c}$ \\
\hline $\begin{array}{l}\text { Three times plowing }+ \text { Pendimethalin } 3 \mathrm{lt} \mathrm{ha}^{-1}+\text { twice } \\
\text { hand weeding at } 3-35 \text { and 50-55DAS }\end{array}$ & $3908.3^{a b}$ & $1384.8^{a b c}$ & $696.75^{\mathrm{a}}$ \\
\hline $\begin{array}{l}\text { Three times plowing }+ \text { twice hand weeding at } 30-35 \text { and } \\
50-55 \text { DAS }\end{array}$ & $2700.0^{\mathrm{def}}$ & 1311.0 abcd & $686.38^{\mathrm{abc}}$ \\
\hline Three times plowing + S-metolachlor $1 \mathrm{lt} \mathrm{ha} \mathrm{ha}^{-1}$ & $2658.3^{\text {efg }}$ & $1098.2^{\text {bcdef }}$ & 675.73 abcd \\
\hline Three times plowing + Pendimethalin $3 \mathrm{lt} \mathrm{ha}^{-1}$ & $3366.7 \mathrm{bcd}$ & $1064.7^{\text {cdef }}$ & 666.43 abcd \\
\hline Three times plowing + weedy check & $3216.7^{\mathrm{bcd}}$ & 1331.0 abcd & $692.83^{\mathrm{ab}}$ \\
\hline LSD (0.05) & 780.19 & 387.01 & 31.099 \\
\hline CV $(\%)$ & 22.85 & 30.35 & 3.99 \\
\hline
\end{tabular}

Note: $C V=$ Coefficient of Variation, $L S D=$ Least significance difference, DAS=Days after sowing, $l t=l i t t e r$, Means followed by the same letter within a column are not significantly different at $0.05 p$ 


\section{R. raphanistrum weed count, height and fresh biomass}

There was significant interaction effect of plowing frequency, application of herbicide and hand weeding on $R$. raphanistrum plant count, height and biomass in faba bean field (Table 3 ). The lowest (18.67 and $\left.21.33 \mathrm{weed} / \mathrm{m}^{2}\right)$ $R$. raphanistrum plant count was recorded from three times plowing + twice hand weeding at 30-35 and 50-55 DAS and three times plowing + application S-metolachlor at $1 \mathrm{lt} \mathrm{ha}^{-1}$ supplemented by twice hand weeding at 3035 and 50-55 DAS, respectively. The highest $\left(62.67\right.$ weeds $\left./ \mathrm{m}^{2}\right)$ weed count was recorded from twice plowing + application of S-metolachlor at $1 \mathrm{lt} \mathrm{ha}^{-1}$ supplemented with twice hand weeding at 30-35 and 50-55 DAS followed by twice plowing + application of S-metolachlor at $1 \mathrm{lt} \mathrm{ha}^{-1}$ supplemented with once hand weeding at 30-35 DAS, but most of treatments showed statistical parity. Therefore, three times plowing + application of S-metolachlor at 1 litter ha $\mathrm{a}^{-1}$ and three times plowing + application S-metolachlor at $1 \mathrm{lt} \mathrm{ha}^{-1}$ supplemented with twice hand weeding at 30-35 and 50-55DAS were effective in reducing $R$. raphanistrum weed population as compared to other treatments.

There was significant interaction effect of plowing frequency, application of herbicide and hand weeding on $R$. raphanistrum weed height and weed biomass in faba bean (Table 3$)$. The shortest $(36.36 \mathrm{~cm}) \mathrm{R}$. Raphanistrum height was recorded from twice plowing + application of Pendimethalin at $3 \mathrm{lt} \mathrm{ha}^{-1}$ supplemented with twice hand weeding at 30-35 and 50-55 DAS followed by three times plowing+ application of Pendimethalin at 3 lt ha ${ }^{-1}$ supplemented with twice hand weeding at 30-35 and 50-55 DAS and three times plowing+ application of Smetolachlor at 1 litter $\mathrm{ha}^{-1}$ supplemented with twice hand weeding at 30-35 and 50-55DAS, respectively, but as par with twice plowing + S-metolachlor at $1 \mathrm{lt} \mathrm{ha}^{-1}$ supplemented with twice hand weeding at 30-35 and 50-55 DAS. The tallest $(126.1 \mathrm{~cm}$ and $124.9 \mathrm{~cm})$ mean $R$. raphanistrum height was recorded from three times plowing + application of pendimethalin at $3 \mathrm{lt} \mathrm{ha}^{-1}$ and three times plowing + application of S-metolachlor at 1 litter ha $\mathrm{ha}^{-1}$, respectively. But non- significantly with twice plowing + Pendimethalin at $3 \mathrm{lt} \mathrm{ha}^{-1}$. This indicted that $R$. raphanistrum height was highly influenced by application of Pendimethalin at $3 \mathrm{lt} \mathrm{ha}^{-1}$ and S-metolachlor at $1 \mathrm{lt}^{-} \mathrm{ha}^{-}$ ${ }^{1}$ when supplemented by twice hand weeding at 30-35 and 50-55 DAS as compared to other treatments. This is because of the fact that $R$. raphanistrum can managed at different germination stage because of the integration of pre emergence herbicide and twice hand weeding at different time.

The lowest weed fresh biomass $(150.0 \mathrm{~kg} / \mathrm{ha}$ and $191.7 \mathrm{~kg} / \mathrm{ha})$ was recorded from three times plowing + application of S-metolachlor at $1 \mathrm{lt} \mathrm{ha}^{-1}$ supplemented with twice hand weeding at 30-35 and 50-55 DAS and three times plowing + application of Pendimethalin at $3 \mathrm{lt} \mathrm{ha}^{-1}$ supplemented with twice hand weeding at 30-35 and 5055 DAS, respectively (Table 3$)$. The highest $(9008.5 \mathrm{~kg} / \mathrm{ha})$ fresh weed biomass was recorded from three times plowing + weedy check. Non-significant different was observed among all treatment which was supplemented by twice hand weeding. The higher weed fresh biomass in weedy check might be due to higher weed density that provided an opportunity for the weeds to compete vigorously for nutrients, space, light, and water and carbon dioxide. These results are in agreement with findings of Alfonso et al., (2013) and Das and Yaduraju, (1999) who reported maximum weed dry weight in weedy check treatments. 
Table 3. Effect of integrated weed management on R. raphanistrum plant count, height and fresh biomass in Waliso district during 2017/2018

\begin{tabular}{|c|c|c|c|}
\hline Treatments & $\begin{array}{ll}R . \quad \text { raphanistrum } \\
\text { weed count } / \mathrm{m}^{2}\end{array}$ & $\begin{array}{l}\text { R.raphanistrum } \\
\text { hieght }(\mathrm{cm})\end{array}$ & $\begin{array}{l}R \text {. raphanistrum fresh } \\
\text { biomass }(\mathrm{kg} / \mathrm{ha})\end{array}$ \\
\hline Year 2017 & $27.833^{b}$ & $106.835^{\mathrm{a}}$ & $2288.5^{b}$ \\
\hline Year 2018 & $48.250^{\mathrm{a}}$ & $50.322^{b}$ & $3311.5^{\mathrm{a}}$ \\
\hline LSD $(0.05)$ & 10.43 & 7.0516 & 571.83 \\
\hline $\begin{array}{l}\text { Twice plowing }+ \text { S-metolachlor } 1 \mathrm{lt} \mathrm{ha}^{-1}+ \\
\text { once hand weeding at } 30-35 \text { DAS }\end{array}$ & $53.33^{\mathrm{ab}}$ & $65.79 \mathrm{de}$ & $2125.0^{\text {def }}$ \\
\hline $\begin{array}{l}\text { Twice plowing }+ \text { S-metolachlor } 1 \mathrm{lt} \mathrm{ha}^{-}+ \\
\text {twice weeding at } 30-35 \text { and } 50-55 \text { DAS }\end{array}$ & $62.67^{\mathrm{a}}$ & $42.29^{\text {fgh }}$ & $266.7^{\mathrm{gh}}$ \\
\hline $\begin{array}{l}\text { Twice plowing+ Pendimethalin } 3 \text { lt ha } \\
{ }^{-}+\text {once hand weeding at } 30-35 \text { DAS }\end{array}$ & $25.33^{\mathrm{bc}}$ & $65.77 \mathrm{de}$ & 1875.0 defg \\
\hline $\begin{array}{l}\text { Twice plowing }+ \text { Pendimethalin } 3 \mathrm{lt} \mathrm{ha}^{-1}+ \\
\text { twice weeding at } 30-35 \text { and } 50-55 \mathrm{DAS}\end{array}$ & $48.00^{a b c}$ & $36.36^{\mathrm{h}}$ & $391.7^{\mathrm{gh}}$ \\
\hline $\begin{array}{l}\text { Twice plowing }+ \text { twice hand weeding at } \\
30-35 \text { and } 50-55 \text { DAS }\end{array}$ & $40.67^{a b c}$ & $58.01 \mathrm{efg}$ & $825.0^{\text {fgh }}$ \\
\hline Twice plowing + S-metolachlor $1 \mathrm{lt} \mathrm{ha}^{-1}$ & $28.67^{\mathrm{bc}}$ & $102.871^{b c}$ & $4416.7^{\mathrm{c}}$ \\
\hline Twice plowing + Pendimethalin $3 \mathrm{lt} \mathrm{ha}^{-1}$ & $28.00^{b c}$ & $112.024^{\mathrm{ab}}$ & $3225.0^{\mathrm{cd}}$ \\
\hline Twice plowing + weedy check & $35.33^{a b c}$ & $85.21^{\mathrm{cd}}$ & $4458.3^{\mathrm{c}}$ \\
\hline $\begin{array}{l}\text { Three times plowing }+ \text { S-metolachlor } 1 \mathrm{lt} \\
\text { ha }^{-1}+\text { once hand weeding at } 30-35 \text { DAS }\end{array}$ & $36.00^{a b c}$ & $97.98^{b c}$ & $2458.3 \mathrm{de}$ \\
\hline $\begin{array}{l}\text { Three times plowing }+ \text { S-metolachlor } 1 \\
\text { ltha }{ }^{-1}+\text { twice hand weeding at } 30-35 \text { and } \\
50-55 \text { DAS }\end{array}$ & $21.33^{\mathrm{c}}$ & $39.11 \mathrm{gh}$ & $150.0^{\mathrm{h}}$ \\
\hline $\begin{array}{l}\text { Three times plowing }+ \text { Pendimethalin3 lt } \\
\text { ha }^{-1}+\text { once hand weeding at } 30-35 \text { DAS }\end{array}$ & $46.00^{a b c}$ & $87.59^{\mathrm{c}}$ & $1300.0^{\text {efgh }}$ \\
\hline $\begin{array}{l}\text { Three times plowing }+ \text { Pendimethalin } 3 \mathrm{lt} \\
\mathrm{ha}^{-1}+\text { twice hand weeding at } 3-35 \text { and } \\
50-55 \mathrm{DAS}\end{array}$ & $28.67^{\mathrm{bc}}$ & $38.89 \mathrm{gh}$ & $191.7^{\mathrm{h}}$ \\
\hline $\begin{array}{l}\text { Three times plowing twice hand } \\
\text { weeding at } 30-35 \text { and } 50-55 \text { DAS }\end{array}$ & $18.67^{\mathrm{c}}$ & 59.09 ef & $366.7^{\mathrm{gh}}$ \\
\hline $\begin{array}{l}\text { Three times plowing }+ \text { S-metolachlor } 1 \mathrm{lt} \\
\mathrm{ha}^{-1}\end{array}$ & $38.67^{a b c}$ & $124.983^{\mathrm{a}}$ & $7491.7^{a b}$ \\
\hline $\begin{array}{l}\text { Three times plowing+ Pendimethalin3 lt } \\
\mathrm{ha}^{-1}\end{array}$ & $54.00^{\mathrm{ab}}$ & $126.133^{\mathrm{a}}$ & $6250.0^{b}$ \\
\hline Three times plowing + weedy check & $43.33^{a b c}$ & $115.144^{\mathrm{ab}}$ & $9008.5^{\mathrm{a}}$ \\
\hline $\operatorname{LSD}(0.05)$ & 29.502 & 19.945 & 1617.4 \\
\hline $\mathrm{CV}(\%)$ & 67.19 & 21.99 & 50.05 \\
\hline
\end{tabular}

Note: $C V=$ Coefficient of Variation, $L S D=$ Least significance difference, DAS=Days after sowing, lt $=$ litter, Means followed by the same letter within a column are not significantly different at $0.05 p$

\section{R. Raphanistrum Management on Economic Feasibility of Faba Bean Production}

Partial budget analysis for different treatments was indicted in table 4 . The value to cost ratio for plowing frequency was 6.62 to 42.01 EB per unit investment. The highest marginal rate of return of $2942 \%$ was obtained from three times plowing with no hand weeding. $R$. raphanistrum management with three times plowing combined with application of Pendamentalin at $3 \mathrm{lt} \mathrm{ha}^{-1}$ supplemented with once hand weeding at 30-35 DAS gave net profit advantage of 23174 EB with marginal rate of return of $187 \%$ followed by three times plowing + application of S-metolachlor at $1 \mathrm{lt} \mathrm{ha-1}$ supplemented with twice hand weeding at 30-35 and 50-55 DAS and twice plowing + application of S-metolachlor at $1 \mathrm{lt} \mathrm{ha}^{-1}$ supplemented with once hand weeding at 30-35 DAS gave net benefit of 22352 and 21208 EB per hectare with marginal rate of return of 527 and $29 \%$, respectively (Table 4). The economic analysis confirmed that $R$. raphanistrum weed management on faba bean was profitable with three times plowing + application of Pendamentalin at $3 \mathrm{lt} \mathrm{ha}^{-1}$ herbicide supplemented with once hand weeding at 3035 DAS or three times plowing + application of S-metolachlor at $1 \mathrm{lt} \mathrm{ha}^{-1}$ supplemented with twice hand weeding at 30-35 and 50-55 DAS for Waliso district. 
Table 4. Effects of integrated R. Raphanistrum management on economic profitability of faba bean during $2017-$ 2018 cropping season

\begin{tabular}{|c|c|c|c|c|c|c|c|c|c|c|}
\hline Treatments & $\begin{array}{l}\text { Grain } \\
\text { yield } \\
\mathrm{kg} / \mathrm{ha}\end{array}$ & $\begin{array}{l}\text { Adjusted } \\
\text { yield } \mathrm{kg} / \mathrm{ha}\end{array}$ & $\begin{array}{l}\text { Gross field } \\
\text { benefit } \\
(\mathrm{EB} / \mathrm{ha})\end{array}$ & $\begin{array}{l}\text { Herbicide } \\
\text { cost } \\
(\mathrm{EB} / \mathrm{ha})\end{array}$ & $\begin{array}{l}\text { Plowing } \\
\text { cost } \\
(\mathrm{EB} / \mathrm{ha})\end{array}$ & $\begin{array}{l}\text { Weeding } \\
\text { cost } \\
\left(\mathrm{EB} \mathrm{ha}^{-1}\right)\end{array}$ & $\begin{array}{l}\text { TCV } \\
(\mathrm{EB} / \mathrm{ha})\end{array}$ & $\begin{array}{l}\text { Net } \\
\text { benefit } \\
\text { EB }\end{array}$ & $\begin{array}{l}\text { Value } \\
\text { to cost } \\
\text { ratio }\end{array}$ & $\begin{array}{l}\text { MRR } \\
(\%)\end{array}$ \\
\hline $\begin{array}{l}\text { Twice plowing }+ \\
\text { metolachlor } 1 \text { liter ha } \mathrm{h}^{-1}\end{array}$ & 748 & 673.2 & 12117.6 & 0 & 195 & 237 & 432 & 11686 & 27.05 & \\
\hline Twice plowing + weedy check & 1147 & 1032.3 & 18581.4 & 0 & 195 & 237 & 432 & 18149 & 42.01 & \\
\hline $\begin{array}{l}\text { Thrice plowing }+ \text { weedy } \\
\text { check }\end{array}$ & 1331 & 1197.9 & 21562.2 & 0 & 293 & 237 & 530 & 21032 & 39.68 & 2942 \\
\hline $\begin{array}{l}\text { Twice plowing }+ \text { twice hand } \\
\text { weeding at } 30-35 \text { and } 50-55 \\
\text { DAS }\end{array}$ & 1108 & 997.2 & 17949.6 & 0 & 195 & 356 & 551 & 17399 & 31.58 & \\
\hline $\begin{array}{l}\text { three times plowing }+ \text { twice } \\
\text { hand weeding at } 30-35 \text { and } 50 \text { - } \\
55 \text { DAS }\end{array}$ & 1311 & 1179.9 & 21238.2 & 0 & 293 & 356 & 649 & 20589 & 31.72 & \\
\hline $\begin{array}{l}\text { Twice plowing }+ \text { S- } \\
\text { metolachlor } 1 \mathrm{lt} \mathrm{ha} \mathrm{h}^{-1}+\text { once } \\
\text { hand weeding at } 30-35 \text { DAS }\end{array}$ & 1379 & 1241.1 & 22339.8 & 700 & 195 & 237 & 1132 & 21208 & 18.73 & 29 \\
\hline $\begin{array}{l}\text { three times plowing }+ \text { S- } \\
\text { metolachlor } 1 \text { it ha } \mathrm{h}^{-1}+\text { once } \\
\text { hand weeding at } 30-35 \mathrm{DAS}\end{array}$ & 1272 & 1144.8 & 20606.4 & 700 & 293 & 237 & 1230 & 19376 & 15.75 & \\
\hline $\begin{array}{l}\text { three time plowing+ } \mathrm{S} \text { - } \\
\text { metolachlor } 1 \mathrm{lt} \mathrm{ha}^{-1}\end{array}$ & 1098 & 988.2 & 17787.6 & 700 & 293 & 237 & 1230 & 16558 & 13.46 & \\
\hline $\begin{array}{l}\text { Twice plowing+ S- } \\
\text { metolachlor } 1 \mathrm{lt} \mathrm{ha-}+\text { twice } \\
\text { weeding at } 30-35 \text { and } 50-55 \\
\text { DAS }\end{array}$ & 982 & 883.8 & 15908.4 & 700 & 195 & 356 & 1251 & 14657 & 11.72 & \\
\hline $\begin{array}{l}\text { Thrice plowing+ S- } \\
\text { metolachlor } 1 \mathrm{lt} \mathrm{ha-1}+\text { twice } \\
\text { hand weeding at } 30-35 \text { and } 50- \\
55 \text { DAS }\end{array}$ & 1463 & 1316.7 & 23700.6 & 700 & 293 & 356 & 1349 & 22352 & 16.57 & 527 \\
\hline $\begin{array}{l}\text { Twice plowing+ } \\
\text { Pendimethalin } 3 \mathrm{lt} \mathrm{ha}^{-1}+\text { once } \\
\text { hand weeding at } 30-35 \text { DAS }\end{array}$ & 1150 & 1035 & 18630 & 1260 & 195 & 237 & 1692 & 16938 & 10.01 & \\
\hline $\begin{array}{l}\text { Twice plowing+ } \\
\text { Pendimethalin } 3 \mathrm{lt} \mathrm{ha}^{-1}\end{array}$ & 796 & 716.4 & 12895.2 & 1260 & 195 & 237 & 1692 & 11203 & 6.62 & \\
\hline $\begin{array}{l}\text { three times plowing+ } \\
\text { Pendimethalin } 3 \text { lt ha }{ }^{-1}+\text { once } \\
\text { hand weeding at } 30-35 \text { DAS }\end{array}$ & 1541 & 1386.9 & 24964.2 & 1260 & 293 & 237 & 1790 & 23174 & 12.95 & 187 \\
\hline $\begin{array}{l}\text { three times plowing+ } \\
\text { Pendimethalin } 3 \text { lt ha } \mathrm{h}^{-1}\end{array}$ & 1065 & 958.5 & 17253 & 1260 & 293 & 237 & 1790 & 15463 & 8.64 & \\
\hline $\begin{array}{l}\text { Twice plowing+ } \\
\text { Pendimethalin } 31 \mathrm{tha}^{-1}+\text { twice } \\
\text { weeding at } 30-35 \text { and } 50-55 \\
\text { DAS }\end{array}$ & 1093 & 983.7 & 17706.6 & 1260 & 195 & 356 & 1811 & 15896 & 8.78 & \\
\hline $\begin{array}{l}\text { Three times plowing+ } \\
\text { Pendimethalin } 31 \mathrm{ltha}^{-1}+\text { twice } \\
\text { hand weeding at } 30-35 \text { and } 50- \\
55 \text { DAS }\end{array}$ & 1385 & 1246.5 & 22437 & 1260 & 293 & 356 & 1909 & 20528 & 10.75 & \\
\hline
\end{tabular}

\section{Conclusion and Recommendation}

The result of the present study showed that plowing frequency, application of pre emergence herbicide supplemented by hand weeding showed significant increase on yield and yield components of faba bean. The highest mean grain yield $(1541.2 \mathrm{~kg} / \mathrm{ha})$ was obtained from the interaction of three times plowings + application of Pendimethalin at $3 \mathrm{lt} \mathrm{ha}^{-1}$ supplemented with once hand weeding at 30-35 DAS followed by thrice plowing + application of S-metolachlor at $1 \mathrm{lt} \mathrm{ha}^{-1}$ supplemented with twice hand weeding at 30-35 and 50-55 DAS with mean grain yields of (1462.8 kg/ha). Similarly, $R$. raphanistrum weed population, height and fresh biomass were significant due to the interaction effect of the treatments. The lowest $R$. raphanistrum weed population, height and fresh biomass were obtained from the interaction of three times plowing + application of S-metolachlor at $1 \mathrm{lt}$ ha${ }^{1}$ supplemented by twice hand weeding at 30-35 and 50-55 DAS. Economic analysis also showed that three times plowing + application of Pendimethalin at 3 litter ha ${ }^{-1}$ supplemented by once hand weeding at 30-35 DAS gave the highest $23174 \mathrm{~EB}$ Net benefit followed by trice plowing + application S-metolachlor at $1 \mathrm{lt} \mathrm{ha}^{-1}$ supplemented by twice hand weeding at 30-35 and 50-55 DAS gave 22352 EB net benefit. Therefore, three times plowing + application of S-metolachlor at $1 \mathrm{lt} \mathrm{ha}^{-1}$ supplemented with twice hand weeding at 30-35 and 50-55 DAS or three times plowing + application of Pendimethalin at $3 \mathrm{lt} \mathrm{ha}^{-1}$ supplemented with once hand weeding at 30-35 DAS is be recommended for an effective and economical management method of R.raphanistrum and obtain the highest grain yield in Waliso district of South West Shoa Zone. 


\section{References}

Alfonso S, Frenda, Paolo R, Sergio S, Bendetto F, Gjuseppe D, Gaetano A, Dario G. (2013). The critical Period of Weed Control in Faba bean and Chickpea in Mediterranean areas. Weed Science Society of America, 61 (3): 452-459.

Bellido, R.J.,L. Bellido, F.J. Bellido and J.E. Castillo.(2003). Faba bean (Vicia faba L.) response to tillage and soil residual nitrogen in a continuous rotation with wheat (Triticum aestivum L.) under rain-fed Mediterranean conditions. Agron. J.95: 1253-1261.

Brader, L. (1979). Integrated pest control in the developing world. Annual Review of Entomology 24: 225-254

CIMMYT Economics Program, International Maize, \& Wheat Improvement Center (1988) from agronomic data to farmer recommendations: An economics training manual. CIMMYT.

Das Tk, Yaduraju NT. (1999). Effect of weed comptetion on growth, nutrient uptakake and yield of wheat as affected by irrigation and fertilizers. Journal of Agricultural Science, 133(1): 45-51.

Dhaba Feyisa, Tolera Abera and Girma W/Tsadik. (2005). Estimated yield loss in bread wheat (Triticum aestivum) following control of Rapahnus raphanistrum with herbicides and hand weeding. Arem 2005 Volume 6:79-84.

El-Metwally IM, Abdelhamid MT. (2008). Weed competition on growth, nutrient uptake and yield of wheat as affected by irrigation and fertilizers. Journal of Agricultural Science, 133(1): 45-51.

Endale Asmare and Rezene Fessehaie. (1991). Evaluation of tillage and weed control methods in faba bean field at Welmera. Nile Valley Regional Programme on Cool-Season Food Legumes. Annual Report 1989/90, Ethiopia. ICARDA/NVRP-DOC_011.

Hadi H, Ghassemi-Golezani K, Khoei FR, Vaizadeh, M, Shakiba MR, (2006). Response of common bean (Phaseolus vulgaris L.) to different levels of shade. Journal of Agronomy, 5: 595-599.

Hodgson GL, Blackman GE. (2005). An analysis of the influence of plant Density on the Growth of Vicia faba. Journal of Experimental Botany, 48: 147-165.

Pereira GAM, Barcellos JR, Silva DV, Bragam RR, Teixeir M, Silva AA, Ribeiro JR. (2015). Application Height in Herbicides Efficiecy in Bean Crops. Planta Daninha, 33(3) : 607-614.

Retter, L. and Harden, G.J.(2007). Raphanus raphanistrum L. New South Wales Flora Online. Plant NET - The Plant Information Network System of Botanic Gardens Trust. http://plantnet.rbgsyd.nsw.gov.au. Royal Botanic Gardens and Domain Trust, Sydney, New South Wales.

Tolera Abera and Daba Fayisa. (2004). Effect of ploughing frequency, seed rate and weeding frequency on ggronomic parameters of faba bean on farmers fields at Shamboo, Ethiopia. In: Proceeding of the $11^{\text {th }} \mathrm{CSSE}$ Conference, 26-27 april 2004, Addis Ababa, Ethiopia 